\title{
EFFECT OF COMPOST AND SOME NATURAL GROWTH PROMOTING ON CHAMOMILE
}

\author{
M.A.H. Abdou*; R.A. Taha*; A.M.O. Gahory ${ }^{* *}$ and A.A.A. Hassan ${ }^{*}$ \\ * Horticulture Department, Fac. of Agric., Minia Univ. Egypt \\ ** Horticulture Department, Fac. of Agric. and Nat. Resources, Aswan Univ., Egypt
}

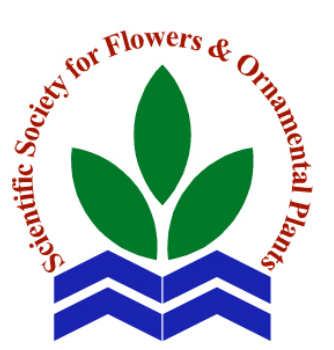

Scientific J. Flowers \& Ornamental Plants, 8(4):447-459 (2021).

Received:

$18 / 10 / 2021$

Accepted:

$12 / 11 / 2021$

ABSTRACT: A field experiment was carried out during the two successive growing seasons of 2019/2020 and 2020/2021 at the Nursery of Ornamental Plants, Faculty of Agriculture, Minia University to study the effect of compost $(0.0,2.5,5.0$ and 7.5 ton/fed) and foliar spray with ascorbic and salicylic acids, each at 50,100 and $200 \mathrm{ppm}$, on growth, productivity of flowers and essential oil of chamomile (Matricaria chamomilla, L.) plants. Results indicated that vegetative growth traits (plant height and number of branches/plant), flowers fresh and dry weights/plant, essential oil (\%) and yield/plant as well as photosynthetic pigments were significantly improved as a result of applied compost at the three levels with the highest values were obtained with 7.5 ton/fed treatment. Also, all concentrations of ascorbic and salicylic acids led to significant increases in all previous characters of vegetative growth, flowers and essential oil productivity compared to control. The combination treatment of compost (7.5 ton/fed) with salicylic acid (200 ppm) was superior than the other interaction treatments.

Corresponding author: M.A.H. Abdou Key words: Matricaria chamomilla, compost, ascorbic acid, salicylic mahmoud.abdo@mu.edu.eg acid, essential oil.

\section{INTRODUCTION}

Chamomile (Matricaria chamomilla L.) belongs to Family Asteraceae. it is widely used as a medicinal plant. It has many active constituents, including the essential oil (Haj Sayed Hadi et al., 2004; Szoke et al., 2004 and Salamon, 2007). The principal components of the essential oil of flowers are $\beta$ - farnesene, farnesol, chomazulene, abisabolol and a-bisabolol oxides, which are known as anti-inflammation, antiseptic spasmolytic and healing action (Jakovlev et al., 1983).

The positive role of compost and the direct relationship between increasing compost levels application and the increment of plant growth and productivity was reported by Hendawy and Khalid (2011).

The efficiency of ascorbic and salicylic acids as antioxidants in improving plant growth, flower and essential oil productivity was emphasized by many authors. Regarding ascorbic acid, Yousef et al. (2005) and Ranjbar et al. (2014). As for salicylic, Abdou et al. (2013); Mazrou (2017) and Sadaghiani et al. (2019).

Therefore, this experiment was aimed to study the effect of compost, ascorbic acid as well as salicylic acids on growth and productivity of chamomile plant.

\section{MATERIALS AND METHODS}

The present investigation was conducted at the Nursery of Ornamental Plants, Faculty of Agriculture, Minia University, during the two successive growing seasons of 2019/2020 and 2020/2021 and the essential oil percentages were determined at the Laboratory of Horticulture Department, Faculty of Agriculture and Natural Resources, Aswan University, to study the 
effect of compost rates and some natural growth regulators (ascorbic acid and salicylic acids) on chamomile (Matricaria chamomilla, L.) plant.

The experiment layout was a randomized complete block design in a split-plot design with three replicates. The main plots (A) included four levels of compost $(0.0,2.5,5.0$ and 7.5 ton/fed), while the sub-plots (B) involved six natural growth regulators treatments (ascorbic acid at 50, 100 and 200 ppm and salicylic acid at 50, 100 and 200 ppm, as well as control), including 28 interaction treatments. The physical and chemical analysis of the used soil are listed in Table (a). Seeds of chamomile plant were sown in the second week of September $\left(15^{\text {th }}\right.$ September), during both seasons, in the beds of the nursery. The seedlings were transplanted at 40 days after sowing $\left(25^{\text {th }}\right.$ October).

Fully decomposed compost (plant residues) was obtained from Egypt Company for Circulate Solid Residues at New ElMinia City and added during preparing the soil to cultivation in both seasons. The chemical analysis of compost is shown in Table (b).

The different concentrations of each ascorbic acid and salicylic acid (50, 100 and 200 ppm) were biweekly applied by hand sprayer 3 times each season, starting on $4^{\text {th }}$ November for each season.

Fresh flower heads were collected (hand picking) when $50 \%$ of the plant was in the blooming stage (last week of December lasted to the end of April) which was continued daily. Every week (each seven days), dry weight of the flowers was calculated after drying the flower heads at room temperature (Hendawy and Khalid, 2011).

\section{Data recorded:}

Vegetative growth (plant height and number of branches/plant), fresh and dry weights of flower heads per plant, essential oil (\%) and essential oil yield/plant, (ml), as well as photosynthetic pigments.

\section{Oil determination:}

The essential oil percentage was determined in dried flower heads samples in both seasons by subjecting to hydro distillation using Clevenger apparatus according to method described by the Egyptian Pharmacopoeia (1984), then the essential oil yield per plant and per feddan were calculated.

\section{Chlorophyll a, b and carotenoids:}

Chlorophyll a, b and carotenoids were determined in fresh samples of leaves $(\mathrm{mg} / \mathrm{g}$ f.w.) according to the method cited from Fadl and Sari El-Deen (1978). The determination was conducted using acetone $(85 \% \mathrm{v} / \mathrm{v})$ as plank at wavelength of 660 , 644 and $440.5 \mathrm{~nm}$ for chlorophyll a, b and carotenoids, respectively. Then calculated using the following equations:

Chl. a $(\mathrm{mg} / \mathrm{g}$ f.w. $)=(9.784 \times$ E 662$)-(0.99$ $\times$ E 644)

Chl. B (mg/g f.w.) $=(21.426 \times$ E 644 $)-$ $(4.65 \times$ E 662)

Carotenoids $(\mathrm{mg} / \mathrm{g}$ f.w. $)=(4.695 \times \mathrm{E} 440.5)$ - 0.268 (E 662 - E 644)

Where: $\mathrm{E}$ the optical density of given wavelength.

The obtained data were tabulated and statistically analyzed according to MSTATC (1986), and L.S.D test at 5\% was followed to compare between the means of treatments

\section{RESULTS AND DISCUSSION}

\section{Vegetative growth traits:}

Data presented in Table (1) indicated that both of plant height and number of branches/plant were significantly increased due to the application of compost at 2.5, 5.0 and 7.5 ton/fed compared to control. The tallest plants $(80.03$ and $90.14 \mathrm{~cm}$ in both seasons, respectively) and the greatest number of branches/plant (25.50 and 22.10 in both seasons, respectively), regardless the effect of ascorbic and salicylic acids, were obtained with a high level of compost. Similar results were recorded by Juárez- 
Table a. Physical and chemical properties of the used soil during the two seasons.

\begin{tabular}{|c|c|c|c|c|c|}
\hline \multirow{2}{*}{ Soil characters } & \multicolumn{2}{|c|}{ Values } & \multirow{2}{*}{ Soil characters } & \multicolumn{2}{|c|}{ Values } \\
\hline & $2019 / 2020$ & $2020 / 2021$ & & $2019 / 2020$ & $2020 / 2021$ \\
\hline \multicolumn{3}{|c|}{ Physical properties: } & \multicolumn{3}{|c|}{ Exchangeable nutrients: } \\
\hline Sand $(\%)$ & 26.78 & 25.60 & $\mathrm{Ca}^{++}$(mg/100 g soil) & 29.21 & 30.03 \\
\hline Silt (\%) & 29.87 & 30.64 & $\mathrm{Mg}^{++}(\mathrm{mg} / 100$ g soil $)$ & 4.45 & 4.65 \\
\hline Clay (\%) & 43.35 & 43.76 & $\mathrm{Na}^{+}(\mathrm{mg} / 100$ g soil $)$ & 2.81 & 2.75 \\
\hline Soil type & Clay loam & Clay loam & $\mathrm{K}^{+}(\mathbf{m g} / \mathbf{1 0 0} \mathrm{g}$ soil $)$ & 2.95 & 2.74 \\
\hline \multicolumn{3}{|c|}{ Chemical properties: } & \multicolumn{3}{|c|}{ DTPA-Extractable nutrients: } \\
\hline pH (1:2.5 paste) & 7.87 & 7.81 & $\mathrm{Fe}(\mathrm{ppm})$ & 7.93 & 7.81 \\
\hline E.C. $(d S / m)$ & 1.12 & 1.10 & $\mathrm{Cu}$ (ppm) & 1.81 & 1.76 \\
\hline O.M. (\%) & 1.44 & 1.49 & Zn (ppm) & 2.47 & 2.48 \\
\hline $\mathrm{CaCO}_{3}(\%)$ & 2.09 & 2.10 & Mn (ppm) & 7.71 & 7.85 \\
\hline
\end{tabular}

Table b. Chemical analysis of the used compost in both seasons of 2019/2020 and 2020/2021.

\begin{tabular}{llll}
\hline Properties & Value & Properties & Value \\
Organic carbon (\%) & 24.3 & Total P (\%) & 0.6 \\
Humidity (\%) & 24.8 & Total K (\%) & 1.1 \\
Organic matter (\%) & 43.4 & Fe (ppm) & 1765 \\
C/N ratio & 17.2 & Zn (ppm) & 62 \\
pH (1:2.5) & 8.10 & Mn (ppm) & 127 \\
E.C. $(\mathbf{m m h o s} / \mathbf{c m})$ & 5.2 & $\mathbf{C u}(\mathbf{p p m})$ & 205 \\
Total N $(\%)$ & 1.6 & & \\
\hline
\end{tabular}

Table 1. Effect of compost, some natural growth regulators and their combinations on plant height and branches number/plant of chamomile during 2019/2020 and 2020/2021 seasons.

\begin{tabular}{|c|c|c|c|c|c|c|c|c|c|c|}
\hline \multirow{3}{*}{$\begin{array}{c}\text { Natural growth regulators } \\
\text { treatments }\end{array}$} & \multicolumn{10}{|c|}{ Compost levels (ton/feddan) (A) } \\
\hline & 0.0 & & 5.0 & 7.5 & $\begin{array}{c}\text { Mean } \\
\text { (B) }\end{array}$ & 0.0 & 2.5 & 5.0 & & $\begin{array}{c}\text { Mean } \\
\text { (B) }\end{array}$ \\
\hline & \multicolumn{6}{|c|}{$1^{\text {st }}$ season $(2018 / 2019)$} & \multicolumn{4}{|c|}{$2^{\text {nd }}$ season $(2019 / 2020)$} \\
\hline & \multicolumn{10}{|c|}{ Plant height (cm) } \\
\hline Control & 51.75 & 53.58 & 55.50 & 57.58 & 54.60 & 62.08 & 64.16 & 64.53 & 87.24 & 69.51 \\
\hline Ascorbic acid (50 pl & 53.16 & 54.41 & 57.75 & 63.99 & 57.43 & 63.75 & 70.41 & 75.41 & 87.49 & 74.26 \\
\hline Ascorbic acid (100 ppm) & 61.08 & 68.83 & 68.91 & 76.74 & 68.89 & 66.66 & 72.83 & 82.91 & 89.16 & 77.89 \\
\hline id $(200 \mathrm{ppm})$ & 72.49 & 80.58 & 82.16 & 85.49 & 80.18 & 62.08 & 84.58 & 86.00 & 86.25 & 84.73 \\
\hline 150 nom & 74.83 & 76.16 & 80.41 & 87.08 & 79.37 & 79.83 & 84.37 & 85.33 & 87.91 & 84.36 \\
\hline Salicylic acid (100 ppm) & 84.99 & 87.91 & 93.41 & 93.75 & 90.01 & 74.16 & 74.99 & 92.66 & 95.83 & 84.41 \\
\hline Salicylic acid (200 ppm) & 88.08 & 92.74 & 94.99 & 95.58 & 92.85 & 88.58 & 89.33 & 94.74 & 97.08 & 92.61 \\
\hline Me & 69.54 & 73.31 & 76.23 & 80.03 & & 64.78 & 67.18 & 83.10 & 90.14 & \\
\hline \multirow[t]{2}{*}{ L.S.D at $5 \%$} & \multicolumn{2}{|c|}{ A: 2.5} & B: 2.0 & \multicolumn{2}{|c|}{$\mathrm{AB}$ : } & \multicolumn{2}{|c|}{ A: 2.9} & B: 2.2 & \multicolumn{2}{|c|}{ AB: 4.4} \\
\hline & \multicolumn{10}{|c|}{ Branches number/plant } \\
\hline C & 12.26 & 12.78 & 13.35 & 14.49 & 13.19 & $11.75^{*}$ & 12.28 & 12.75 & 13.99 & 12.69 \\
\hline 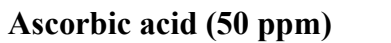 & 1425 & 14.91 & 17.49 & 18.99 & 16.41 & 13 & 14.41 & 16.99 & 18.49 & 15.91 \\
\hline Ascorbic acid (100 ppm) & 17.99 & 21.99 & 22.49 & 22.75 & 21.30 & 17.49 & 21.49 & 21.99 & 22.25 & 20.80 \\
\hline Ascorbic acid (200 ppm) & 18.75 & 19.99 & 22.58 & 25.08 & 21.60 & 18.25 & 19.49 & 22.08 & 24.58 & 21.10 \\
\hline Salicylic acid (50 ppm) & 14.33 & 17.08 & 20.58 & 24.91 & 19.22 & 13.83 & 16.58 & 20.08 & 24.41 & 18.72 \\
\hline (100 nnm) & 15.33 & 20.08 & 22.41 & 23.83 & 20.41 & 14.83 & 19.58 & 21.91 & 23.32 & 19.91 \\
\hline Salicylic acid (200 ppm) & 16.66 & 20.66 & 23.66 & 27.49 & 22.11 & 16.23 & 20.23 & 23.23 & 27.06 & 21.92 \\
\hline Mean (A) & 15.65 & 18.21 & 20.35 & 22.50 & & 15.16 & 17.81 & 19.95 & 22.10 & \\
\hline L.S.D at $5 \%$ & \multicolumn{2}{|c|}{ A: 1.51} & B: 0.62 & \multicolumn{2}{|c|}{ AB: 1.24} & \multicolumn{2}{|c|}{ A: 1.48} & B: 0.54 & \multicolumn{2}{|c|}{ AB: 1.58} \\
\hline
\end{tabular}


Rosete et al. (2012); Haj Seyed Hadi et al. (2015); Rabie et al. (2017) and Gandomi et al. (2021) on chamomile plants.

Also, data in Table (1) mentioned that all used concentrations of ascorbic and salicylic acids significantly increased plant height and number of branches/plant, and salicylic acid at $200 \mathrm{ppm}$ recorded the tallest plants $(92.85$ and $92.61 \mathrm{~cm}$ ) and highest values number of branches/plant (22.11 and 21.92), in both seasons, respectively). In agreement with our results concerning the promotion effect of salicylic acid Mazrou (2017) and Sadaghiani et al. (2019), also, Yousef et al. (2005) and Ranjbar et al. (2014) on chamomile, Ali (2004) and Abdul-Basit et al. (2018) on Tagetes sp. Al-Shareif (2006) and Elgohary et al. (2020) on caraway and Elbohy et al. (2018) on Zinnia elegans. Regarding the effect of ascorbic acid, Attia and Moftah (2003) on borage, Ahmed (2005) on Majorana hortensis, Abdou et al. (2009) on fennel plants, Eid et al. (2011) on Tagetes erecta, L., Ewais et al. (2012) on sunflower and Mostafa (2018) on dragonhead plant.

The interaction between the two factors was significant for plant height and number of braches/plant. The combined treatment of 7.5 ton/fed compost and salicylic acid (200 ppm) was superior to the other interaction treatments.

\section{Fresh and dry weights of flower heads:}

Data in Table (2) indicated that all compost levels $(2.5,5.0$ and 7.5 ton/fed) significantly increased flower fresh and dry weights/plant in both seasons as compared to control. Application of compost at 7.5 ton/fed recorded the heaviest fresh weights (142.06 and $139.13 \mathrm{~g} / \mathrm{plant}$ ) and dry weights (26.40 and $25.95 \mathrm{~g} / \mathrm{plant}$ ), in both seasons, respectively. The positive effects of compost on enhancing flowering weights were obtained by Hendawy and Khalid (2011); Chand et al. (2012); Haj Seyed Hadi et al. (2015); Aleman et al. (2016); Ahmadian et al. (2018); Monjezi et al. (2018); Salehi et al. (2018) and Gandomi et al. (2021) on chamomile plants and Nazari et al. (2008);
Hassan et al. (2014); Idan et al. (2014); Singh et al. (2015) and Sharma et al. (2017) on marigold plants.

Regarding the effect of antioxidants (ascorbic and salicylic acids), from that all levels used (50-200 ppm) significantly enhanced fresh and dry flowers weights/plant as compared to the control (Table, 2). The highest values of fresh and dry weights were obtained by salicylic acid followed by ascorbic acid each at $200 \mathrm{ppm}$ as recorded 147.21 and $143.65 \mathrm{~g} / \mathrm{plant}$ followed by 141.14 and $136.29 \mathrm{~g} / \mathrm{plant}$ in the first and second seasons, respectively. While, the best dry flowers weight/plant was resulted for salicylic acid (200 ppm) as gave 29.67 and $29.01 \mathrm{~g} / \mathrm{plant}$, in both seasons, respectively. Many investigators found similar effects of salicylic acid as Abdou et al. (2013) and Mazrou (2017) on chamomile, Ali (2004) on Tagetes minuta, Khandaker et al. (2011) on Amaranthus tricolor, FarjadiShakib et al. (2012) on Cyclamem persicum, Ghorbani et al., (2013) on violet flower, Choudhary et al. (2017); Kumar et al. (2019) and Sadique et al. (2021) on Tagetes erecta, L. plants and Niri et al. (2016); Kumar (2017) and Abdul-Basit et al. (2018) on marigold. concerning the effect of ascorbic acid, Yousef et al. (2005) and Ranjbar et al. (2014) on chamomile plants, Attia and Moftah (2002) and Abd El-Latif (2007) on borage plants, Ewais et al. (2012) on Helianthus sp., Elbohy et al. (2018) on Zinnia, and Azizi et al. (2021) on Calendula officienalis, obtained similar results.

The interaction was significant and the heaviest weights were obtained with the application of compost at 7.5 ton/fed, combined with spraying plants with salicylic acid at $200 \mathrm{ppm}$.

\section{Oil productivity:}

Essential oil (\%) and oil yield per plant were augmented due to compost fertilization $(2.5,5.0$ and 7.5 ton/fed $)$. The best results of essential oil \% (1.36 and 1.42) and essential oil yield/plant (36.81 and $37.93 \mathrm{ml})$ in both seasons, respectively, were obtained with 
Table 2. Effect of compost, some natural growth regulators and their combinations on flower heads fresh and dry weights (g/plant) of chamomile during 2019/2020 and 2020/2021 seasons.

\begin{tabular}{|c|c|c|c|c|c|c|c|c|c|c|}
\hline \multirow{3}{*}{$\begin{array}{c}\text { Natural growth regulators } \\
\text { treatments }\end{array}$} & \multicolumn{10}{|c|}{ Compost levels (ton/feddan) (A) } \\
\hline & 0.0 & 2.5 & 5.0 & 7.5 & $\begin{array}{c}\text { Mean } \\
\text { (B) }\end{array}$ & 0.0 & 2.5 & 5.0 & 7.5 & $\begin{array}{c}\text { Mean } \\
\text { (B) }\end{array}$ \\
\hline & \multicolumn{5}{|c|}{$1^{\text {st }} \operatorname{season}(2018 / 2019)$} & \multicolumn{5}{|c|}{$2^{\text {nd }}$ season $(2019 / 2020)$} \\
\hline & \multicolumn{10}{|c|}{ Flower heads fresh weight (g/plant) } \\
\hline C & & 5 & 61 & 57.62 & 54.36 & 46.28 & 53.04 & 53 & & 5 \\
\hline 180 & & & & & & & 94.27 & & & \\
\hline Ascorbic : & 121.53 & 123.53 & 137.86 & 141.44 & 131.09 & 116 & 116.96 & 45 & & 126 \\
\hline & & 13 & 14 & 16 & 141.14 & & 12 & 134 & 16 & 13 \\
\hline & & & 7 & 16 & 116 & & 10 & & & \\
\hline & & 7 & .59 & 168 & 132 & & 12 & 132.43 & & \\
\hline Sal & 114 & 13 & & 176 & 147.21 & 108 & 13 & 157.16 & 175.36 & 143.65 \\
\hline Mea & .49 & 105 & 106.11 & 142.06 & & 87.56 & 106.04 & 121.16 & 139.13 & \\
\hline \multirow[t]{2}{*}{ L.S.D at $5 \%$} & \multicolumn{2}{|c|}{ A: 9.12} & B: 8.52 & \multicolumn{2}{|c|}{ AB: 16.04} & \multicolumn{2}{|c|}{ A: 10.01} & B: 8.99 & \multicolumn{2}{|c|}{ AB: 17.98} \\
\hline & \multicolumn{10}{|c|}{ Flower heads dry weight (g/plant) } \\
\hline & & & 13.43 & 16 & $13.49^{\circ}$ & 11 & 12.01 & 13.09 & & \\
\hline & & & 23.76 & & 22.55 & & & 22.93 & & \\
\hline Asc & 2 & 23. & 26.01 & & 24.53 & & & & & 23 \\
\hline Asco & 23.35 & 26.43 & 27.09 & 28.51 & 26.34 & 22.85 & 25.93 & 26.59 & 28.18 & 25.89 \\
\hline & & & 21.09 & 28.18 & 21.22 & & & 20.18 & & \\
\hline Salic & 17.26 & 21.84 & 25.67 & 28.34 & 23.28 & 16.85 & 21.51 & 25.26 & 28.26 & 22.97 \\
\hline Salic & 26.93 & 28.09 & 30.84 & 32.83 & 29.67 & 26.34 & 27.51 & 30.26 & 31.93 & 29.01 \\
\hline Mea & 19.80 & 21.88 & 23.97 & 26.40 & & 19.19 & 21.33 & 23.39 & 25.95 & \\
\hline L.S.D at $5 \%$ & \multicolumn{2}{|c|}{ A: 2.11} & B: 1.85 & \multicolumn{2}{|c|}{$\mathrm{AB}: 3.76$} & \multicolumn{2}{|c|}{ A: 2.00} & B: 1.73 & \multicolumn{2}{|c|}{ AB: 3.46} \\
\hline
\end{tabular}

compost at 7.5 ton/fed as shown in Table (3). Similar results were recorded by Mazrou (2017); Sadaghiani et al. (2018) and (2019) on chamomile plants.

Concerning the effects of ascorbic and salicylic acids treatments (Table, 3), these treatments significantly stimulated the essential oil (\%) and yield/plant, compared to the control in both seasons. Sparing chamomile plants with salicylic acid at 200 ppm significantly increased the production of oil, giving the highest essential oil \% (1.48 and 1.55) and essential oil yield/plant (44.33 and $45.58 \mathrm{ml}$ ), in both seasons, respectively.

The capability of antioxidants especially salicylic acid on essential oil (\%) and yield/plant were detected by Abdou et al. (2013) and Mazrou (2017) on chamomile plants. In regard to the effect of ascorbic acid, Yousef et al. (2005) and Ranjbar et al. (2014) on chamomile, Yousef and Talaat (2003) on rosemary, Reda et al. (2005) on Thymus, Ayat (2007) and Said et al. (2014) on coriander plants, Ibrahim (2010) and ElLeithy et al. (2011) on geranium, Mostafa (2018) on dragonhead mentioned that ascorbic acid treatments increased essential oil percentage.

The interaction effect between the two studied factors on essential oil (\%) and yield/plant was significant in both seasons (Table, 3). The highest values were observed by using 7.5 ton/fed compost in combination with salicylic acid (200 ppm) as a foliar spray.

\section{Photosynthetic pigments:}

Data in Table (4) clarified that the treatments of $2.5,5.0$ and 7.5 ton/fed compost significantly increased the photosynthetic pigments contents (chlorophyll a, b and carotenoids). The highest values for the previous three photosynthetic contents were obtained with the high level of compost (7.5 ton/fed). These results are in harmony with those recorded by Sakr (2001) and Abdou et al. 
Table 3. Effect of compost, some natural growth regulators and their combinations on essential oil (\%) and yield/plant $(\mathrm{ml})$ of chamomile during 2019/2020 and 2020/2021 seasons.

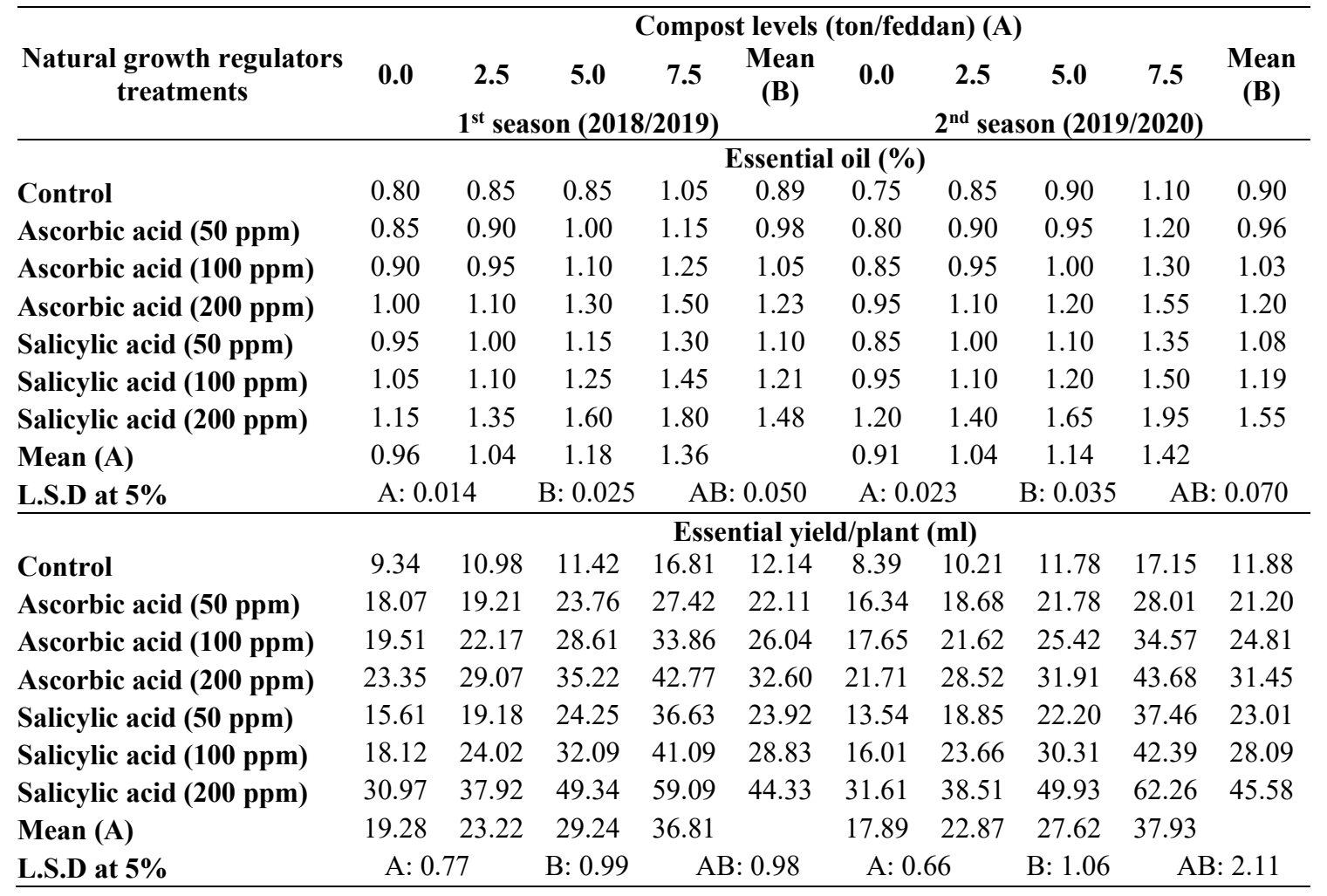

(2012) on mint plant, Khalil et al. (2002); ElMaadawy (2007) and Dikr and Belete (2017) on Tagetes erecta, L., Kandeel and AbouTaleb (2002); Mohsen (2002); Kandeel (2004); El-Sanafawy (2007) and Abdou et al. (2011 and 2014) on Ocimum spp., and ElSherbeny et al. (2005) on Sideritis montana.

Photosynthetic pigments contents were significantly increased as a result of spraying chamomile plants with all used antioxidant concentrations compared to the control in both seasons. The highest contents of pigments were recorded with the high level of salicylic acid (200 ppm), followed by ascorbic acid at $200 \mathrm{ppm}$, with significant differences were detected in most cases.

Our results are in agreement with those obtained by, Mazrou (2017), on chamomile plants, Attia and Moftah (2003) on borage plants, Khalil et al., (2010); Abd El-Salam (2014) and Marzok et al. (2017) on sweet basil plants, Choudhary et al. (2016) on African marigold plants, Niri et al. (2016) on marigold plants, Abdul-Basit et al. (2018); Abbas et al. (2019) and Kumar et al. (2019) on Tagetes sp. regarding salicylic acid treatments. At the same time, Attia and Moftah (2002) on borage plants, Ahmed (2005) on marjoram, Reda et al. (2005) on Thymus, Farahat et al. (2007), on Cupressus sempavirens, Ayat (2007) on coriander plants, Ewais et al. (2012) on sunflower plants, Elbohy et al. (2018) on Zinnia plants, and Mostafa (2018) on dragonhead, regarding the effect of ascorbic acid.

The interaction between compost fertilization and the natural growth regulators treatments (ascorbic and salicylic acid acids) was significant for the three photosynthetic pigments as compared to control in both seasons. The combined treatment compost ( 7.5 ton/fed) and salicylic 
Table 4. Effect of compost, some natural growth regulators and their combinations on chlorophyll a, b and carotenoids (mg/g f.w.) of chamomile during 2019/2020 and $2020 / 2021$ seasons.

\begin{tabular}{|c|c|c|c|c|c|c|c|c|c|c|}
\hline \multirow{3}{*}{$\begin{array}{c}\text { Natural growth regulators } \\
\text { treatments }\end{array}$} & \multicolumn{10}{|c|}{ Compost levels (ton/feddan) (A) } \\
\hline & $\mathbf{0 . 0}$ & 2.5 & 5.0 & 7.5 & $\begin{array}{c}\text { Mean } \\
\text { (B) }\end{array}$ & $\mathbf{0 . 0}$ & 2.5 & 5.0 & 7.5 & $\begin{array}{c}\text { Mean } \\
\text { (B) }\end{array}$ \\
\hline & \multicolumn{5}{|c|}{$1^{\text {st }} \operatorname{season}(2018 / 2019)$} & \multicolumn{5}{|c|}{$2^{\text {nd }} \operatorname{season}(2019 / 2020)$} \\
\hline & \multicolumn{10}{|c|}{ Chlorophyll a (mg/g f.w.) } \\
\hline Control & 1.995 & 2.108 & 2.216 & 2.338 & 2.164 & 2.012 & 2.092 & 2.172 & 2.253 & 2.133 \\
\hline Ascorbic acid (50 ppm) & 2.045 & 2.150 & 2.265 & 2.392 & 2.213 & 2.102 & 2.182 & 2.264 & 2.345 & 2.223 \\
\hline Ascorbic acid (100 ppm) & 2.085 & 2.180 & 2.298 & 2.412 & 2.243 & 2.192 & 2.272 & 2.353 & 2.434 & 2.312 \\
\hline Ascorbic acid (200 ppm) & 2.225 & 2.220 & 2.436 & 2.461 & 2.335 & 2.283 & 2.374 & 2.454 & 2.534 & 2.403 \\
\hline Salicylic acid (50 ppm) & 2.075 & 2.180 & 2.296 & 2.433 & 2.246 & 2.132 & 2.212 & 2.294 & 2.375 & 2.253 \\
\hline Salicylic acid (100 ppm) & 2.105 & 2.201 & 2.319 & 2.426 & 2.262 & 2.232 & 2.312 & 2.393 & 2.474 & 2.352 \\
\hline Salicylic acid (200 ppm) & 2.275 & 2.271 & 2.488 & 2.502 & 2.384 & 2.433 & 2.414 & 2.504 & 2.586 & 2.484 \\
\hline Mean (A) & 2.115 & 2.187 & 2.331 & 2.423 & & 2.195 & 2.264 & 2.348 & 2.429 & \\
\hline \multirow[t]{2}{*}{ L.S.D at $5 \%$} & \multicolumn{2}{|c|}{ A: 0.025} & B: 0.017 & \multicolumn{2}{|c|}{ AB: 0.034} & \multicolumn{2}{|c|}{ A: 0.035} & B: 0.025 & \multicolumn{2}{|c|}{ AB: 0.050} \\
\hline & \multicolumn{10}{|c|}{ Chlorophyll b (mg/g f.w.) } \\
\hline Control & 0.668 & 0.700 & 0.728 & 0.769 & 0.716 & 0.661 & 0.687 & 0.715 & 0.742 & 0.701 \\
\hline Ascorbic acid (50 ppm) & 0.672 & 0.740 & 0.873 & 0.887 & 0.793 & 0.691 & 0.717 & 0.745 & 0.772 & 0.731 \\
\hline Ascorbic ac & 0.681 & 0.751 & 0.882 & 0.896 & 0.802 & 0.720 & 0.748 & 0.774 & 0.801 & 0.760 \\
\hline Ascorbic acid (200 ppm) & 0.693 & 0.768 & 0.899 & 0.976 & 0.822 & 0.751 & 0.778 & 0.808 & 0.835 & 0.793 \\
\hline Salicylic acid (50 ppm) & 0.682 & 0.757 & 0.880 & 0.896 & 0.804 & 0.701 & 0.728 & 0.755 & 0.786 & 0.742 \\
\hline Salicylic acid (100 ppm) & 0.690 & 0.765 & 0.891 & 0.901 & 0.811 & 0.734 & 0.761 & 0.787 & 0.815 & 0.774 \\
\hline Salicylic acid (200 ppm) & 0.705 & 0.779 & 0.905 & 0.941 & 0.832 & 0.800 & 0.806 & 0.824 & 0.852 & 0.813 \\
\hline Mean (A) & 0.674 & 0.751 & 0.865 & 0.880 & & 0.722 & 0.746 & 0.772 & 0.793 & \\
\hline \multirow[t]{2}{*}{ L.S.D at $5 \%$} & \multicolumn{2}{|c|}{ A: 0.017} & B: 0.015 & & $: 0.030$ & A: 0 . & & B: 0.010 & $\mathrm{AB}$ & $: 0.020$ \\
\hline & \multicolumn{10}{|c|}{ Carotenoids (mg/g f.w.) } \\
\hline Control & \multicolumn{2}{|c|}{0.685} & 0.722 & \multicolumn{2}{|c|}{0.759} & \multicolumn{2}{|c|}{0.799} & 0.741 & \multicolumn{2}{|c|}{0.691} \\
\hline Ascorbic acid (50 ppm) & \multicolumn{2}{|c|}{0.702} & 0.770 & \multicolumn{2}{|c|}{0.804} & \multicolumn{2}{|c|}{0.817} & 0.773 & \multicolumn{2}{|c|}{0.721} \\
\hline Ascorbic acid (100 ppm) & \multicolumn{2}{|c|}{0.722} & 0.785 & \multicolumn{2}{|c|}{0.821} & \multicolumn{2}{|c|}{0.833} & 0.790 & \multicolumn{2}{|c|}{0.752} \\
\hline Ascorbic acid (200 ppm) & \multicolumn{2}{|c|}{0.735} & 0.797 & & .834 & 0.8 & & 0.803 & & .782 \\
\hline Salicylic acid (50 ppm) & 0.71 & & 0.781 & & .812 & 0.8 & & 0.785 & & .731 \\
\hline Salicylic acid (100 ppm) & 0.73 & & 0.802 & & .934 & 0.9 & & 0.854 & & .764 \\
\hline Salicylic acid (200 ppm) & 0.75 & & 0.817 & & .956 & 0.9 & & 0.881 & & .831 \\
\hline Mean (A) & 0.72 & & 0.782 & & .845 & 0.8 & & & & .753 \\
\hline L.S.D at $5 \%$ & A: 0. & & B: 0.019 & $\mathrm{AB}$ & $: 0.038$ & A: 0 . & & B: 0.008 & $\mathrm{AB}$ & $: 0.016$ \\
\hline
\end{tabular}

acid (200 ppm) produced the highest contents of chlorophyll a and carotenoids, whereas, the highest content of chlorophyll b was obtained with compost 7.5 ton/fed combined with salicylic acid or ascorbic acid each at $200 \mathrm{ppm}$ in the first season and in the second one.

From the obtained results, it could be discussed as follows: the promoting effect of compost in chamomile plants may be attributed to the role of compost in physiological and biological process (Bohan et al., 1985).

The enhancement of growth, flowers yield and essential oil production due to spraying plants with ascorbic and salicylic acids might be attributed to the positive, biological and physiological roles of those substances as antioxidant that protect the plant against damage and as promoting where they induce flowering retard senescence and augmented the rate of cell metabolic and salicylic acid may be a 


\section{M.A.H. Abdou et al.}

prerequisite for auxin and/or plays an important role as coenzyme (Popova et al., 1997).

\section{REFERENCES}

Abbas, S.M.; Ahmad, R.; Waraich, E.A. and Qasim, M. (2019). Exogenous application of salicylic acid at different plant growth stages improves physiological processes in marigold (Tagetes erecta L.). Pak. J. Agric. Sci., 56(3):541-548.

Abd El-Latif, M.T.M. (2007). Effect of Some Fertilization and Antioxidant Treatments on Borage Plants. M.Sc. Thesis, Fac. Agric., Minia Univ., Egypt, $95 \mathrm{p}$.

Abd El-Salam, N.M.K. (2014). Response of Sweet Basil Plants to Some Agricultural Treatments. Ph.D. Thesis, Fac. Agric., Minia Univ., Egypt, 184 p.

Abdou, M.A.H.; Abdalla, M.Y.; Helaly, A. and Marzok, Z. (2011). Physiological studies on basil plant. J. Agric. Sci. Mansoura Univ., 36(11):1451-1469.

Abdou, M.A.H.; Attia, F.A.; Ahmed, E.T. and Abd El-Naeem, L.M. (2012). Physiological studies on mint plants. Proc. Second Inter. Conf. of Physiol. Microb. And Ecological Plant Sci. (29-30 April, 2012), Fac. of Science, Minia Univ., Egypt: pp. 207-228.

Abdou, M.A.H.; Attia, F.A.; Taha, R.A. and Tanious, C. (2009). Effect of some organic, biofertilization and antioxidant treatments on fennel plants. Proc. $5^{\text {th }}$ Inter. Conf. of Sustain, Agric. and Develop. Fac. of Agric., Fayoum Univ., 21-23. December, pp. 159-178.

Abdou, M.A.H.; Badran, F.S.; El-Sayed, A.A.; Taha, R.A. and Abd Ef-Salam, N.M.K. (2014). Response of sweet basil plants to some agricultural treatments. Minia J. Agric. Res. \& Develop., 34(1):21-31.

Abdou, M.A.H.; Taha, R.A. and Salah ElDeen, R.M. (2013). Influence of some natural substances on growth, flower yield and essential oil of chamomile (Matricaria chamomilla, L.) plants. J. Agric. Res. Kafr El-Sheikh Univ., 39(4):606-615.

Abdul-Basit, K.S.; Ur Rahman, M.; Xing, L.; Zuo, X.; Han, M.; Alam, N.; Fayaz Khan, F.; Ahmed, I. and Khalid, M.A. (2018). Salicylic acid an emerging growth and flower inducing hormone in marigold (Tagetes sp. L.). Pure Appl. Biol., 7(4):1301-1308.

Ahmadian, A.; Ghanbari, A.; Siahsar, B.; Haydari, M.; Ramroodi, M. and Mousavinik, S.M. (2018). Study of chamomile's yield and its components under drought stress and organic and inorganic fertilizers using and their residue. Advanced Journal of Microbiology Research, 12(8):1-6.

Ahmed, M.T. (2005). Physiological Studies on Marjoram (Majorana hortensis, L.) Plants. M.Sc. Thesis, Fac Agric., Zagazig Univ., (Banha branch) Moshtohor, Egypt, $172 \mathrm{p}$

Aleman, C.C.; Marques. P.A.A. and Pacheco, C. (2016). Irrigation and organic fertilization on the production of essential oil and flavonoid in chamomile. Revista Brasileira de Engenharia Agrícola e Ambiental, 20(12):1045-1050.

Ali, A.F. (2004). The benefits of using some natural sources of phosphate and salicylic acid on Tagetes minuta, L. plants. Minia Res. \& Devlop., 24(4):621-648.

Al-Shareif, A.M.O. (2006). Response of Caraway Plants Grown in Sandy Soil Under Drip Irrigation System to Some Bio-Fertilization and Antioxidant Treatments. M.Sc. Thesis. Fac. Agric. Minia Univ. Egypt, 122 p.

Attia, F.A. and Moftah, A.E. (2003). Response of lead-polluted borage (Borago officinalis, L.) to antioxidant treatments. J. Agric. Sci. Mansoura Univ., 27(6):4063 - 4082. 
Ayat, A.M.M. (2007). Effect of Fertilization With Macro, Micro Nutrients and Antioxidants on Coriander (Coriandrum sativum, L.) Plants Growth in New Reclaimed Land. M.Sc. Thesis, Fac. Agric., Minia Univ., Egypt, 112 p.

Azizi, F.; Farsaraei, S. and Moghaddam, M. (2021). Application of exogenous ascorbic acid modifies growth and pigment content of Calendula officinalis L. flower heads of plants exposed to $\mathrm{NaCl}$ stress. Journal of Soil Science and Plant Nutrition, 21:2803-2814.

Bohan, H.L.; Meneul, B.L. and Connar, G.A.O. (1985). Soil Chemistry, $2^{\text {nd }}$ ed., Awiley Interscience Publication. John Wiley and Sons, New York, 368 p.

Chand, S.; Pandey, A. and Patra, D.D. (2012). Influence of vermicompost on dry matter yield and uptake of $\mathrm{Ni}$ and $\mathrm{Cd}$ by chamomile (Matricaria chamomilla) in Ni- and Cd-polluted soil. Water Air Soil Pollut., 223: 2257-2262.

Choudhary, A.; Mishra, A.; Bola, P.K.; Moond, S.K. and Dhayal, M. (2016). Effect of foliar application of zinc and salicylic acid on growth, flowering and chemical constitute of African marigold cv. Pusa Narangi Gainda (Tagetes erecta L.). Journal of Applied and Natural Science, 8(3):1467-1470.

Choudhary, A.; Mishra, A.; Rolaniya, M.K.; Dhayal, M.; Choudhary, R. and Sharma, A. (2017). African marigold is response to foliar application of zinc and salicylic acid. Chemical Science Review and Letters (Chem. Sci. Rev. Lett.), 6(21):305-308

Dikr, W. and Belete, K. (2017). Review on the effect of organic fertilizers, biofertilizers and inorganic fertilizers (NPK) on growth and flower yield of marigold (Tagetes erecta L.). Academic Research Journal of Agricultural Science and Research, 5(3):192-204.

Egyptian Pharmacopoeia (1984). Egyptian Pharmacopoeia, General Organization for
Governmental. Printing Office, Ministry of Health, Cairo, Egypt, pp. 31-33.

Eid, R.A.; Taha, L.S. and Ibrahiem, S.M.M. (2011). Alleviation of adverse effects of salinity on growth and chemical constituents of marigold plants by using glutathione and ascorbate. J. Appl. Sci. Res., 7(5):714-721.

Elbohy, N.F.S; Attia, K.E. and Noor ElDeen, T.M. (2018). Increasing quality of Zinnia elegans plants by foliar spraying with ascorbic and salicylic acids. Middle East Journal of Agriculture Research, 7(4):1786-1797.

Elgohary, A.M.M.; Dawh, A.K.; Gendy, A.S.H. and Abdelkader, M.A.I. (2020). Response of caraway (Carium carvi, L.) growth and yield components to NPKMg fertilizer rate and antioxidants type. Zagazig J. Agric. Res., 47(4):883-894.

El-Leithy, S.; Ayad, H. and Reda, F. (2011). Effect of riboflavin, ascorbic acid and dry yeast on vegetative growth, essential oil pattern and antioxidant activity of geranium (Pelargonium graveolens, L.). American-Eurasian J. Agric. and Enveron. Sci., 10(5):781-786.

El-Maadawy, E.I. (2007). Response of summer annual flowering plants to chemical, organic and bio-fertilization treatments. II- African marigold (Tagetes erecta, L.) plants. J. Product. and Dev., 12(1):173-199.

El-Sanafawy, S.E.A. (2007). Effect of Some Fertilization Treatments on Ocimum basilicum and Origanum majoranum. Ph.D. Thesis, Fac. Agric., Kafr ElSheikh, Tanta Univ., Egypt, 155 p.

El-Sherbeny, S.E.; Khalil, M. and Naguib, N.Y. (2005). Influence of compost levels and suitable spacing on the productivity of Sideritis montana, L. plants recently cultivated under Egyptian conditions. Bull. Fac. Agric., Cairo Univ., 56: 373392.

Ewais, E.A.; Sharaf, A.M.; Abd El-Azim, E.A.; Ismail, M.A. and Amin, M.A. 
(2012). Effect of ascorbic acid, benzyl adenine and paclobutrazol on growth, yield and some metabolic constituents of sunflower plants. Az. J. Pharm Sci., 46: 53-63.

Fadl, M.S. and Sari El-Deen, S.A. (1978). Effect of N6-benzyl adenine on photosynthetic pigments and total soluble sugars of olive seedlings grown under saline conditions. Egypt. J. Hort., 6(2):169-183.

Farahat, M.M.; Ibrahim, S.M.M.; Taha, L.S. and El-Quesni, F.E.M. (2007). Response of vegetative growth and some chemical constituents of Cupressus sempervirens, L. to foliar application of ascorbic acid and zinc at Nubaria. World Journal of Agricultural Sciences, 3(4):496-502.

Farjadi-Shakib, M.; Naderi R. and Boojar, M.A. (2012). Effect of SA application on morphological, physiological and biochemical characteristics of Cyclamen persicum Miller. Annals. of Bio. Res. 3(12):5631-5639.

Gandomi, A.; Amiri, B.; Sharafzadeh, S.; Bazrafshan, F. and Hazrati, S. (2021). The response of different fertilizer applications on chamomile production and their quality characteristics. Acta Sci. Pol. Hortorum Cultus, 20(2):107-119.

Ghorbani, N.; Moradi, H.; Akbarpour, V. and Ghasemnezhad, A. (2013). The phytochemical changes of violet flower (Viola cornuta) response to exogenous salicylic acid hormone. Journal of Chemical Health Risks, 3(4):1-8.

Haj Seyed Hadi, M.R.; Fallah, M.A. and Mohammad Taghi Darzi, M.T. (2015). Influence of nitrogen fertilizer and vermicompost application on flower yield and essential oil of chamomile (Matricaria chamomile L.). Journal of Chemical Health Risks, 5(3):235-244.

Haj Seyed Hadi, M.R.; Noormohamadi, G.; Masoud-Sinaki, J.; Khodabandeh, N.; Yasa, N. and Darzi, M.T. (2004). Effects of planting time and planting density on flower yield and active substances of chamomile (Matricaria chamomilla L.). In: Fourth International Crop Science Congress, Brisbane, Australia.

Hassan, A.E.; Bhiah, K.M. and Al-Zurfya, M.T.H. (2014). Effect of organic extracts on the growth and flowering of marigold plants (Calendula officinalis L.). Journal of Organics (JO), 1(1):22-30.

Hendawy, S.F. and Khalid, A.K. (2011). Effect of chemical and organic fertilizers on yield and essential oil of chamomile flower head. Medicinal and Aromatic Plant Science and Biotechnology, 5(1):43-48.

Ibrahim, T.I.E.I. (2010). Physiological Studies on Geranium Plants. M.Sc. Thesis, Fac. Agric. Minia Univ., Egypt, $160 \mathrm{p}$.

Idan, R.O.: Prasad, V.M. and Saravanan, S. (2014). Effect of organic manures on flower yield of African marigold (Tagetes erecta L.) cv. Pusa Narangi Gainda. International Journal of Agricultural Science and Research (IJASR), 4(1):7-18.

Jakovlev, V.; Isaac, O. and Flaskamp, E. (1983). Pharmacological with compounds of chamomile (VI) investigation on the antiphlogistic effects of chamazulene and matricine. Planta Medica, 49(2):67-73.

Juárez-Rosete, C.R.; Rodriguez-Menndoza, M.N.; Aguilar-Castillo, J.A. and TrejoTellez, L.I. (2012). Inorganic and organic fertilization in biomass and essential production of Matricaria recutita L. Acta Hort., 947:307-311.

Kandeel, A.M. and Abou-Taleb, N.S. (2002). Effect of some organic manures on the growth, volatile oil yield and chemical composition of Ocimum basilicum, L. plant. Zagazig J. Agric., Res., 29(6):1839-1857.

Kandeel, Y.M.R. (2004). Effects of bioorganic and chemical fertilization on the growth, essential oil productivity and 
chemical composition of Ocimum basilicum, L. plant. Annals. of Agric. Sci., Moshtohor, 42(3):1253-1270.

Khalil, M.Y. (2002). Influence of compost and foliar fertilization on growth and chemical composition of Rosmarinus officinalis, L. Egypt., J. of Appl. Sci., 17(10):648-699.

Khalil, S.E.; Abd El-Aziz, N.G. and Abou Leil, B.H. (2010). Effect of water stress and ascorbic acid on some morphological and biochemical composition of Ocimum basilicum plant. J. American Sci., 6(12):33-44.

Khandaker, L.; Masum Akond, A.S.M.G. and Oba, S. (2011): Foliar application of salicylic acid improved the growth, yield and leaf's bioactive compounds in red amaranth (Amaranthus tricolor, L.). Vegetable Crops Research Bulletin, 74: 77-86.

Kumar, P. (2017). Effect of PGRs on Growth, Flowering and Seed Production in Marigold cv. Pusa Narangi Gainda. M.Sc. Thesis, Sher-E-Kashmir University of Agricultural Sciences and Technology of Jammu, $84 \mathrm{p}$

Kumar, P.; Singh, A.; Laishram, N.; Pandey, RK.; Al Dogra, S.; Jeelani, MI. and Sinha, BK. (2019). Effects of plant growth regulators on quality flower and seed production of marigold (Tagetes erecta L.). Bangladesh J. Bot., 49(3):567577.

Marzok, Z.S.A. (2017). Effect of Plant Spaces, Active Yeast and Some Vitamins on Basil Plant. Ph.D. Thesis, Fac. Agric., Minia Univ., Egypt, 161 p.

Mazrou, R.M. (2017). Salt stress alleviation of chamomile plant by mycorrhizal fungi and salicylic acid. International Journal of Current Microbiology and Applied Sciences, 6 (10):5099-5111.

Mohsen, M.M.A. (2002). Sweet Basil Herb and Oil Production as Affected by Chemical and Organic Fertilization.
M.Sc. Thesis, Fac. Agric., Cairo Univ., Egypt, 167 p.

Monjezi, S.; Norouzi Masir, M.; Moezzi, A.A. and Mahmoodi Sourestani, M. (2018). Effect of some organic and chemical fertilizers on zinc uptake and growth indices of German chamomile (Matricaria chamomilla L.). J. of Soil Management and Sustainable Production, $8(2): 63-82$.

Mostafa, H.S. (2018). Complementary effect between compost rate and ascorbic acid concentration on enhancing dragonhead (Dracocephalum moldavica) plant on growth and productivity. Middle East Journal of Agriculture Research, 7(4):1811-1818.

MSTAT-C, (1986). A microcomputer program for the design management and analysis of agronomic research experiments (Version 4), Michigan State Univ., USA.

Nazari, F.; Farahmand, H.; Eshghi, S.; Niki, M. and Eslamzade, M. (2008). The effect of different soil amendments on growth and flowering of African marigold (Tagetes erecta 1.) 'queen'. Journal of Fruit and Ornamental Plant Research, 16:403-415.

Niri, D.F.; Saffari, V.R. and Maghsoudi, Moud A.A. (2016). Effect of salicylic acid on photosynthetic pigments and chlorophyll florescence of pot marigold under salt stress conditions. Iranian Journal of Horticultural Science and Technology, 17(1):77-88.

Popova, L.; Pancheva, T. and Uzunova, A. (1997). Salicylic acid: properties, biosynthesis and physiological role. Bulg. 1. Plant Physiolg., 23:85-93.

Rabie, K.A.E.; Ashour, H.M. and Ali, F.S.I. (2017). Growth characters and some chemical constituents of Matricaria chamomilla L. plants in relation to green manure and compost fertilizer in sandy soil. Middle East Journal of Agriculture, 6(1):76-86. 


\section{M.A.H. Abdou et al.}

Ranjbar, B.; Sharafzadeh, S. and Alizadeh, O. (2014). Growth and essential oil responses of German chamomile to thiamine and ascorbic acid. Bulletin of Environment, Pharmacology and Life Sciences, 3(7):51-53.

Reda, F.; Abdel-Rahim, E.A.; El-Baroty, G.S. and Ayd, H.S. (2005). Response of essential oils, phenplic compounds and polyphenyl oxidase activity of thyme (Thymus vulgaris) to some bioregulators and vitamins. International J. Agric. and Biol., 7(5):735-739.

Sadaghiani, F.M.; Dehaghi, M.A.; Pirzad, A.R. and Fotokian, M.H. (2018). Interaction of late season drought stress and foliar application of osmolytes on the yield and yield components of German chamomile (Chamomilla recutita L.). Iranian Journal of Medicinal and Aromatic Plants, 34(3):492-508.

Sadaghiani, F.M.; Dehaghi, M.A.; Pirzad, A.R. and Fotokian, M.H. (2019). Variation in yield and biochemical factors of German chamomile (Matricaria recutita L.) under foliar application of osmolytes and drought stress conditions. Journal of Herbmed Pharmacology, 8(2):90-100.

Sadique, S.; Ali, M.M.; Usman, M.; Hasan, M.U.; Yousef, A.F.; Adnan, M.; Gull, S.; Nicola, S. (2021). Effect of foliar supplied pgrs on flower growth and antioxidant activity of African marigold (Tagetes erecta L.). Horticulturae, 7(10):1-17.

https://doi.org/10.3390/horticulturae 7100 378

Said, A.H.; El-Gendy, A.G. and Omer, E.A. (2014). Effect of ascorbic acid and salicylic acid on coriander productivity and essential oil and cultivated in two different locations. Advances in Environmental Biology, 8(7):2236-2250.

Sakr, W.R.A.S. (2001). Effect of Some Organic and Inorganic Fertilizers on Mentha piperita, L. M.Sc, Thesis, Fac. Agric., Cairo Univ., Egypt, 147 p.
Salamon, I. (2007). Effect of the internal and external factors on yield, qualitative and quantitative characteristics of chamomile essential oil. The Proc. of the $1^{\text {st }}$ International Symposium on Chamomile Research, Development and Production, $31^{\text {st }}$ August, 2007, Presov, Slovak Republic, Acta Hortic. 749:45-65.

Salehi, A.; Gholamhoseini, M.; Ataei, R.; Sefikon, F. and Ghalavand, A. (2018). Effects of zeolite, bio- and organic fertilizers application on German chamomile yield and essential oil composition. Journal of Essential Oil Bearing Plants, 21(1):116-130.

Sharma, A.; Saha, T.N.; Arora, A.; Shah, R. and Nain, L. (2017). Efficient microorganism compost benefits plant growth and improves soil health in calendula and marigold. Horticultural Plant Journal, 3(2):67-72.

Singh, L.; Gurjar, P.K.S.; Barholia, A.K.; Haldar A. and Shrivastava A. (2015). effect of organic manures and inorganic fertilizers on growth and flower yield of marigold (Tagetes erecta L.) var. Pusa Narangi Gainda. Plant Archives, 15(2):779-783.

Szoke, E.; Maday, E.; Kiss, S.A.; Sonnewend, L. and Lemberkovies, E. (2004). Effect of magnesium on essential oil formation of genetically transformed and no transformed chamomile cultures. Journal of American Nutrition, 23:76357675 .

Yousef, A.A. and Talaat, I.M. (2003). Physiological response of rosemary plants to some vitamins. Egypt. Pharm. J., 1: 81-90.

Yousef, A.A.; Aziz, A.A. and Talaat, I.M. (2005). Influence of some antioxidants on growth, flower-heads and essential oil content of Matricaria chamomilla, L. plants. Annals Agric. Sci., Moshtohor, 43(2):823-832. 


\section{تأثير الكمبوست وبعض منشطات النمو الطبيعية علي الكاموميل}

محمود عبدالهادي حسن"، رجاء علي طه"، عبدالله محمد عثمان جهوري"*، أميرة عبدالقادر أحمد حسن"

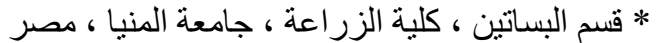

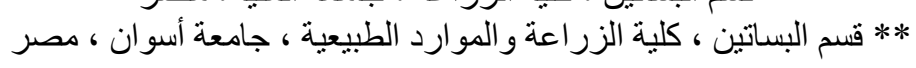

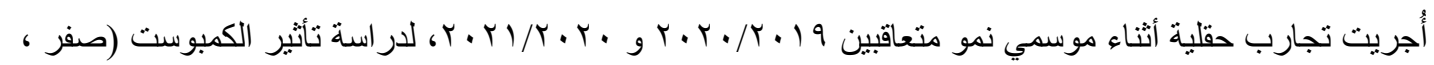

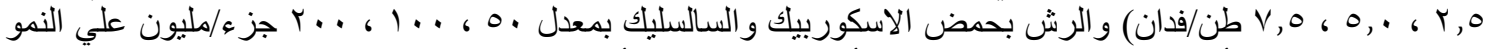

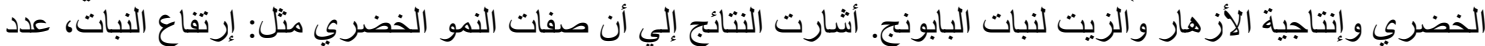

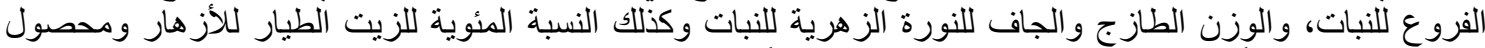

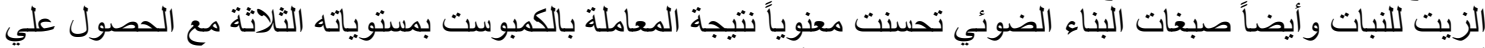

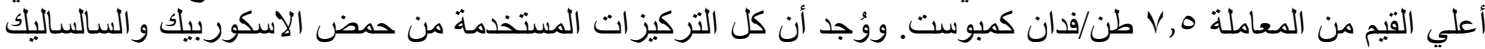

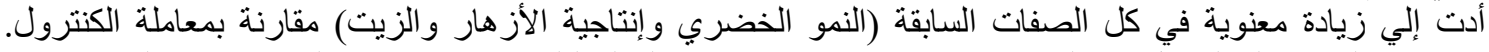

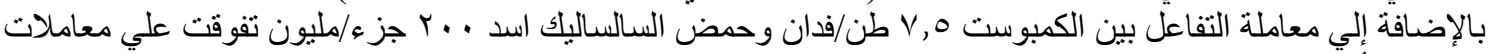

